In $24 \mathrm{~h} 11$ per cent of the radioactivity was detected in the urine, which consisted of the parent compound and two important metabolites. Tissue residues were less than 0.1 p.p.m. 21 days after oral administration of $50 \mathrm{mg} / \mathrm{kg}$ of the compound labelled with carbon-14.

A single oral dose of $500 \mathrm{mg} / \mathrm{kg}$ was well tolerated by sheep and swine. The oral $L D_{50}$ for rats and mice exceeds $4 \mathrm{~g} / \mathrm{kg}$.
P. ACTOR
E. L. ANDERSON
C. J. DiCuollo
R. J. Fertauto
J. R. E. HoOver
J. F. Pagano
L. R. RAVIN
S. F. SCHEIDY
R. J. STEDMAN
V. J. THWODORIDES

Smith Kline and French Laboratories, 1500 Spring Garden Street,

Philadelphia, Pennsylvania.

Received April 28; revised May 25, 1967.

\section{Toxic Strain of Fusarium culmorum (W.G.Sm.) Sace. from Zea mays L., associated with Sickness in Dairy Cattle}

IN 1928 there was an extensive North American outbreak of "scab" in barley, caused by the fungus Gibberella zea (Schw.) Potch syn. G. saubinetti (conidial stage Fusarium graminearum Schw.). This was followed by the publication of a number of papers on the offect of feeding infected grain to domostic animals.

Bohstcdt and Dickson ${ }^{1}$ reported that ruminants showed no ill effects, but animals with simple stomachs, particularly pigs, were found to be vory sensitive to "scab" infected grain. Mundkur ${ }^{2}$ carried out feeding tests with hogs which demonstrated that barley containing 40 per cent scabby grain caused vomiting and slight intoxication but no diarrhoea or entcritis. Prentice et al. ${ }^{3}$ extracted emotic material from culture filtrates of the following Fusarium species: $F$. moniliforme (ono strain), $F$. poae, $F$. culmorum and $F$. nivale, when grown on synthetic liquid culture media. The only report of "fusariotoxicosis" in cattlo seoms to come from Russia, whero oats infocted with a very toxic strain of $F$. sporotrichiella produced poisoning symptoms when fed to yearling calves ${ }^{4}$.

I'ho condition reported here occurred towards the end of autumn (May 1966), in south-eastern Victoria, at Berwick and Drouin, which are situated about 25 and 55 miles, respoctively, from Molbourno. In both localities loss of appetite and decreased milk production were reported in dairy cattle after feeding on a crop of maize (Zea mays L.). At Berwick seven cows in a herd of fortyfive showod loss of appotito and marked reduction in milk yicld after feeding on maize; in addition some were scouring maize and two exhibited symptoms of staggering. Recovery and return to normal milk production occurred within a weck of removing the cows from the maize crop.

When samples of the suspect maize crops were submitted to the Victorian Plant Research Institute for mycological examination, several specics of Fusarium were isolated. Two wero cultured from Drouin maize: $F$. culmorum (W.G.Sm.) Sace. from the bract of a male inflorescenco and $F$. graminearum Schwabe from the nodal region of the stem.

These species were also isolated from Berwick specimons of maize; $F$. culmorum was cultured from nodal stcm tissue and $F$. graminearum from the bract of a cob. Also from the nodal stem tissue of Berwick maize plants the following additional species were cultured: $F$. acuminatum Ell. and Ev., F. moniliforme Sheld., and an unidentified species, resembling but distinct from $F$. dimerum. All Fusarium species isolated were tested for dermal toxicity using the method described by Forgacs and Carll ${ }^{5}$. The fungal cultures to be tested were grown on sterilized maize grain for two weeks at $21^{\circ} \mathrm{C}$ and then extracted with other in a cold Soxhlet apparatus. The dried ether extract was suspended in $2 \mathrm{ml}$. of olive oil and applied to a circular shaved patch of rabbit skin 2 in. in diameter. In each test, five applications of about $0.1 \mathrm{ml}$. of oily suspension were given during 2.5 days. The test was negative for all species except $F^{\prime}$. culmorum; however, isolants of this fungus from both Drouin and Berwick produced a very severe reaction. This species was tested on three rabbits. In each instance, the skin reddened on the third day, progressing in intensity and forming a typical haemorrhagic lesion, until finally death of the rabbit ensued on the fifth, sixth and seventh days, rospectively.

We thank Dr C. Booth of the Commonwcalth Mycological Institute, Kew, for identification of the Fusarium isolants.

EILeen E. Fismer

A. W. KELLOCK

N. A. M. WELLINGTON

Victorian Department of Agriculture,

Victorian Plant Research Institute and

Division of Animal Health,

Melbourne.

Received January 31, 1967.

1 Bohstedt, G., and Dickson, J. G., Phytopathology, 20, 132 (1930).

2 Mundkur, B. B., Phytopathology, 24, 1237 (1934).

'Prentice, N., Dickson, A. D., and Dickson, J. G., Nature, 184, 1319 (1959).

‘ Kurmanov, I. A., Trudy vses Inst. vet. Sanit., 23, 187 (1964).

${ }^{5}$ Forgacs, J., and Carll, W. T., Advances in Veterinary. Science, 7, 273 (1962).

\section{ANTHROPOLOGY}

\section{Hereditary Deficiency of Pseudocholinesterase in Eskimos}

HIGH susceptibility to the neuromuscular blocking action of succinylcholine is usually associated with a defective form of pseudocholinesterase in blood plasma; the abnormal enzyme is distinguished by its resistance to inhibition by dibucaine ${ }^{1}$. The geno frequency of this abnormality in Caucasians is estimated to be 0.019 ; 3.8 per cent of the population are heterozygous; and $I$ in 2,800 individuals is sensitive to succinylcholine ${ }^{2}$.

A much rarer form of sensitivity to succinylcholine results from the absence in serum of pseudocholinesterase ${ }^{3}$. Only ten cases in seven farnilies have been reported ${ }^{4}$. The frequency of this "silent" gene has been estimated at about 0.003 in Caucasians, and one person in about 100,000 lacks pseudocholinesterase ${ }^{5}$.

Two Lskimo children were apnoeic for 3-4 h after administration of a single doso of succinylcholine amounting to $1 \mathrm{mg} / \mathrm{lb}$. of body weight. The children came from tho same geographical area but were unrelated. When their sera were tested no psoudocholinesterase activity could be demonstrated. While testing random samples of sorum to determine the reliability and reproducibility of the enzyme method, tho thirteenth sample proved to $b \Theta$ from an Eskimo who also lacked psendocholinosterase.

A survey was then made of 708 samples of serum from hospital paticnts. Four unrelated persons among 354 southern Eskimos were found with pscudocholinesteraso deficiency. No abnormal sera were found in 122 northern Eskimos, 141 Athabascan Indians, fifty-eight Aleuts or thirty-three persons of other ethnic groups. None of the samples was resistant to inhibition by dibucaine, except 